\title{
A REVIEW ON BIO-DIESEL PRODUCTION FROM WASTE COCKING OIL VIA ACIDS CATALYSIS
}

\author{
Dinesh Nichat ${ }^{1}$, D.B.Shelke ${ }^{2}$ \\ ${ }^{l}$ Department of Mechanical Engineering, D.Y.Patil School of Engineering Academy, Talegaon (Ambi), Savitribai \\ Phule Pune University, Maharashtra, India. \\ ${ }^{2}$ Department of Mechanical Engineering, D.Y.Patil School of Engineering Academy, Talegaon (Ambi), Savitribai \\ Phule Pune University, Maharashtra, India.
}

\begin{abstract}
Exploring renewable energy sources is the need of present fuel scenario; the petro-fuels are vanishing more rapidly to meet heavy demands of today's population. The Bio-fuels looks attractive and inviting source in this situation. Bio-diesel as a fuel of this category are more environmental benefits as a cleaner fuel compare to the petrol-diesel. Bio-diesel is the product of the process known as a 'stratification' in which Triglycerides from soybean oil reacts with alcohol under action of certain catalysts at specific constant temperature for specific time interval to produce bio-diesel as a result. Bio-diesel can be use in internal-combustion engine as a fuel application solely or blending with petrol-diesel. Lots of benefits of using biodiesel as a fuel it is renewable source, burns cleaner than petrol-diesel and compatible with petrol-diesel. Bio-diesel can be produced through many techniques including acid \& base catalysis, enzymatic conversion, solid catalysis, non-catalytic conversion and super-critical methanolysis
\end{abstract}

Keywords: Biodiesel, Acid Catalyst, Transesterification

\section{INTRODUCTION}

Bio-energy is that the general term for any sort of renewable energy made of organic materials. Bio-fuels are only one sort of bio-energy. Specifically, they're transportation fuels (ethanol and biodiesel) made of renewable resources like corn and soybeans. The assembly of each bio-energy and bio-fuels spurs economic development in rural areas and brings new ventures to those communities that otherwise wouldn't commonly see investment. Bio-energy and biofuels comes produce jobs for our state's employees and is a very important market place for Indian agricultural product, boosting agricultural profits. Bio-energy and production give a chance for like a shot addressing our energy security problems by exploitation domestic crops to provide fuel and renewable waste to make energy. Biofuels production reduces our dependence on foreign sources of oil by exploitation renewable energy. Most biofuels are environmentally superior and contain little sulfur and no virulent chemicals and may replace or be a substitute for dirtier fuel sources. Exploitation of biofuels will scale back hydrocarbons emissions, particulate emissions and carbon monoxide gas emissions. Bioenergy production offers an answer to waste management, by changing waste into usable energy as an example, eutherian mammal waste and wood waste are wonderful sources of energy. By exploitation these renewable sources of energy, we are able to scale back the consequences, like odor, of waste on our communities and surroundings.

Engineers designed the compression ignition engine also called as "diesel" engine around 1890's. A very few modifications have been done in the essential style over a span of time. Compression of fuel occurs in diesel engine which leads to rise of the pressure and temperature to such an extent that the combusts of it which drives the engine as well as moving the vehicle in a forward direction. The diesel engines are used especially in buses as they supply the ability and fuel potency to hold serious numerous passengers upto a long distance. The diesel engines have given monumental advantages to the country's transport system. The first compression ignition engine was used by Sir Rudolph diesel in 1898, in which the fuel was diesel. Use of vegetable oils in the diesel engines was carried on, however it created a change to standard oil diesel, thanks to its comparatively cheaper cost, convenience, as well \&potency. Internal-combustion engine plays necessary role in Indian economy and conjointly contributes to pollution considerably. These engines are employed in generators, Carrier trucks, local buses, farm instrumentality, mines instrumentality etc. Nowadays the employment of diesel engines has raised due to their characteristics like less fuel consumption and a high efficiency. Moreover, diesel engines are being widely used in transportation, electricity generation, agriculture, building construction, marine industry and several other industrial works.

It's possible to scale back waste matter remains in exhaust fumes by exploitation of completely altered fuels. In the diesel engine, different additives are used for decreasing the exploitation of mostly petroleum based fuels and pollutants in exhaust fumes.

India needs major responsiveness for the contentment of energy requirements of a farmer. Irrigation needs to be improved at a massive scale, however at a similar time diesel oil usage should be unbroken to a slightest level due to the cost of diesel as well as its inadequacy. The rise in 
usage of diesel in agricultural sector and transport sectors has led to diesel crises. Oil and electricity are two major fuels that are employed in agriculture sector. Thanks to mechanized farming the amount of energy consumed has raised multifold since independence in terms of oil and electricity.

\subsection{Hydrocarbons in Liquid Form}

Basically engine fuels are the fusions of hydrocarbons, with bonds among hydrogen atoms \& carbon atoms. At the time of combustion these bonds break \& new bonds get generated along with the oxygen atoms, simultaneously with the release of chemical. The major yields are $\mathrm{CO}_{2}$ and water vapors02.

\subsection{Alcohols}

Alcohols include methanol, ethanol, propanol, butanol as compounds.

\section{A) Methanol}

It is generated from natural gas, it has near and long-term potential and an enormous octane quality. It can be used at a very low-concentration i.e. around $5-15 \%$ in gasoline to increase octane number of the mixture. There are some limitations to the use methanol that is poor solubility with gasoline, poisonous, lower energy about $1 / 2$ of gasoline, higher latent heat of vaporization \& $\mathrm{O}_{2}$ amount contribute low drivability, unsuitability with some metals.

\section{B) Ethanol}

Ethanol is obtained from biomass. It has high octane no. and can be used in low concentrations in gasoline. Ethanol is a type of alcohol fuel made with the help of sugars in the grains, as corn, barley, sorghum etc. About 99 percent of the ethanol produced is utilized in the production of E10/ gasohol, a combination of $10 \%$ ethanol \& $90 \%$ gasoline. Anengine powered by gasolineis able to utilize E10, although somespecifically manufactured can use E85 for working, a fuel which is $85 \%$ ethanol and $15 \%$ gasoline.

\section{3) Gaseous Fuels}

\section{A) Compressed Natural Gas (CNG)}

Compressed Natural Gas (“CNG"), an efficient replacement for gasoline ("petrol"), propane, or diesel. Though when it is combusted, it produces greenhouse gases, it is comparatively a good alternative to those fuels by environment point of view, and it is safer than other fuels if anyhow it spills. CNG also mixed with the biogas, created from waste water or landfills, which does not intensify the carbon concentration in the atmosphere. $\mathrm{CNG}$ is created by the compression of natural gas below $1 \%$ of the total vol. CNGlodges after std.atm. Pressure is reached. It is distributed \& preserved in containers up to a pressure of around 200 bar-248 bar [2,900-3,600 psi].

\section{B) Propane (LPG)}

Propane is as efficient as gasoline, the cost reduction is around $15 \%$ as compared to. Moreover, it gives much cleaner burning as compared to gasoline and is safer for engine.

\subsection{Vegetable Oil as Fuels}

Biodiesel, a renewable ammunition created from beastly fats or vegetable oils, is accepted an area of abundant automotive house owners $\&$ agile managers seeking to abate emissions and abutment U.S. activity security. queries typically seem regarding the activity of supply cars with path edible fat (SVO), or decay oils from cordial and adscititious processes, when boilerplate process. However SVO and decay oils adapt from biodiesel (and accepted diesel) in some necessary suggests that and area unit regarding not suggested adequate automotive fuels for panoptic or imperishable use. The seam engineering abstract indicates that the utilization of SVO ends up in discount engine life, non-heritable by the accretion of carbon deposits central the engine and therefore the accretion of SVO within the engine material. These problems area unit as a result of SVO's prime pliability and prime baking purpose close to the acceptable baking scope for agent fuel. The carbon accretion doesn't essentially seem sugar apple aloft use of SVO; it regarding takes abode over the continued term. Compared to agent fuel, all of the vegetable oils area unit copious adscititious viscous, area unit copious acknowledging to atomic number 8 , and settle for faculty billow purpose and cascade purpose temperatures. Imperishable operation after-effects in operational and backbone issues. Some board settle for explored modifying cars to heat SVO above-named to bang into engines. Remaining settle for suggested fusions of edible fat and accepted diesel. Such techniques might abate these issues to a less quantity however don't decimate them entirely. Studies have shown that the carbon accretion (coking) continues with the time, consistent in faculty engine repairs prices and/or below engine span of life.

Viscousness is another necessary thought associated with the utilization of SVO. The viscousness of SVO is way over that of fuel at traditional operational temperatures. High fuel viscousness will cause premature wear of the fuel pumps. It can also considerably change the structure of the fuel spray popping out of the injectors: increasing driblet size, decreasing spray angle, and increasing spray penetration. These effects tend to extend wetting of the engine's internal surfaces, thereby diluting the engine material and increasing the tendency for choking. The semi-permanent impact of mistreatment SVO in diesel engines equipped with trendy emission management systems is additionally a matter of concern. Buildup of fuel within the material is additional vital in these engines even for rock oil diesel and would possibly be severe with the SVO. Basically, these systems weren't actually designed to accommodate the properties of SVO, and that they are often seriously broken. SVO are often purchased within the style of colza oil, sunflower-seed 
oil, soya bean oil, peanut oil, or oil. SVO are often refined from WVO (Waste vegetable oil) just like biodiesel, temperature of SVO from WVO must be increased \& filtration should be done throughout process. The systems area unit abundant less complicated and fewer dear in comparison with biodiesel systems. Rising temperature of WVO to create SVO is done solely for getting rid of suspended wetness. Filtering ensures that solid particulates should not come into a vehicle equipment. There are no chemicals concerned with the WVO - SVO method. Heating element must be ready to raise the temperature of WVO to $140^{\circ} \mathrm{F}$. At now, the $\mathrm{H} 2 \mathrm{O}$ molecules are not any longer suspended within the oil and drop to all-time low of the vessel. Filter is required for getting rid of particles that might impede a equipment. One metric linear unit is that the suggested most filtration size. By process the oil there to level, a ten metric linear unit filter put in within the vehicle will last up to 9000 miles process systems are often easy because the user desires them to be a straightforward five gallon processor are often product of a poster stock pot placed on a stove. Filtering is often done by a 1 metric linear unit sock. However, it might not be sensible for giant scale. Base kits are often nonheritable, up to as cheap as $\$ 700$, whereas the foremost dear kit costs $\$ 2000$. The benefit of paying extra amount is that, it has inflated refinement capability \& therefore the ensuing higher quality of fuel. The $\$ 2000.00$ kit has 255-gallon drums for process, at the side of a centrifuge. The centrifuge gives the benifit of polishing the oil. It acts just like a washer by centrifuging the water \& any particles because the WVO is processed through it. The SVO which is not centrifuged features a level of sludge in it, no matter what proportion filtering is completed. Because of centrifugation, the oil features a unvarying liquid continuity. This results additional SVO that can be used \&therefore the property to employ the ultimate SVO containers when process, SVO has a mean cetane rating of 177 and is significantly additional viscous. SVO are often used as Associate in nursing additives inpetro diesel during this form. The characteristics of S.V.O \&diesel permit it to create a whole blend once it has over twenty fifth SVO partial combustion problems will arise in colder environmental conditions. Thus, it ends up in poor atomization and carbon deposits. Gradually with time, internal engine elements will get worn untimely. Thus, at least right now, it can't be a substitute for diesel, however are often thought of a fuel extender. If calculations area unit created to make sure the share of SVO adscititious to fuel is below 2 hundredth, the mix might be thought of a fall in fuel supply at hotter climate. An alternative choice to use SVO is raising its temperature within the automobile prior to use. Already heating the SVO can drop the viscousness \& lift the cetane rating for being just like diesel. SVO's viscousness is regarding $10 \mathrm{X}$ to $20 \mathrm{X}$ that of diesel at close temperatures. Though, if it was raised to $70^{\circ}$, the viscousness goes down \&therefore the cetane rating will increase forty to fifty, regarding a similar as diesel. A standard internalcombustion engine doesn't have spark plugs \&depends only on compression of air to heat the fuel/air mixture to some extent wherever it'll motorcar ignite. This happens around $500^{\circ}$. SVO features a slightly higher motorcar ignition purpose, however can still combust in a very internal- combustion engine if the engine is said to be in its traditional operational temperature prior to the introduction of SVO. A similar issue of partial combustion exists if the diesel is made dilute over twenty fifth with SVO. Attributable to the partial burning of SVO, there's a prospect of deposits forming within the fuel injectors at the side of oil ring protruding and inflated carbon deposits. So as to stop such phenomenon, the engine should be purged of all SVO $\&$ came back to the operating principle of diesel before ending. Diesel works in a way of cleaner for lines, injectors, $\&$ pistons. Purging just about removes adscititious engine wear. Moreover, if SVO remains there within fuel lines, it'll block the lines creating difficulties for restarting.

\section{REVIEW ON BIODIESEL}

Biodiesel is a liquid form of bio-fuels produced with the help of chemical reactions from animal fats or vegetable or natural oil as well as a type alcohol that possess the ability to get utilized in the diesel operated engines, individually or blend formation with diesel. ASTM International [American Society for Testing \& Materials]has defined biodiesels as acombination of long-chain monoalkyl esters from the fatty acids produced from replenishable resources, to be implied in diesel engines. Blends with the diesel fuelscan be shown as $(\mathrm{Bx})$, where $(\mathrm{x})$ is the percentage of biodiesel in the mixture. E.g. B10shows a blend with $10 \%$ biodiesel \& $90 \%$ diesel fuel, consequently B0 shows pure petro-diesel.

The aim of achieving greater independency from energy one daymay become possible, through developing biodiesels.

\subsection{ADVANTAGE OF BIODIESEL USE AS A}

\section{FUEL}

I) Its an inexhaustible type of fuel, made from vegetable oils or animal fats.

II) Comparatively less toxicthan diesel fuels.

III) They degrade more rapidly as compared to the diesel fuels, reducing the environment related consequences of biofuels spills.

IV) Lesser creation of contaminants: CO, particulates, polycyclic aromatic HCs, aldehydes.

V) Reduced health related issues, because of less emission of carcinogenic substances.

VI) No generation of $\left(\mathrm{SO}_{2}\right)$ Sulfur di oxide.

VII) High flash point of around (1000C minimum).

VIII) Can be fused with the diesel for every possible ratio; both fuels are merged during thefueling of the vehicles.

IX) Excellent lubricant characteristics. 


\subsection{DISADVANTAGE OF BIODIESEL USE AS A}

\section{FUEL}

I) Slightly high fuel consumption because of the lesser calorific value.

II) A slight high Nitrous Oxide [NOx] generationas compared to the diesel fuel.

III) High freeze temperature as compared to diesel fuel. It can be problematic in cold regions.

IV) May react with and degrade plastics, hoses \&gaskets of natural rubber used in their pure state.

V) It is less stable in nature as compared to diesel fuel, \& thus long-term storage ( 6 months or more) of biodiesel can be unsafe.

\subsection{BIODIESEL PRODUCTION PROCESSES}

The production of biodiesel is from alcohol \& animal fats by the process of transesterification. This converts esteri.e. animal fats or vegetable oil into a blend of fatty acids and esters. The production of biodiesel is done by purifying the mixture of Fatty Acid Methyl Esters (FAME).

There are 3 methods of Biodiesel production.

I) Micro-emulsions

II) Pyrolysis (thermal cracking)

III) Transesterification

\subsection{Properties of Waste cooking Oil}

Waste Cocking Oil has higher Kinetic viscosity, Specific Gravity and Flash Point. The temp. at which Waste Cocking Oil catches fire is high in comparison to the pure diesel fuel. The high flash point of Waste Cocking Oil is a safe property due to the safe storage and transportation convenience at room temperature.

Table - 1.1 Properties of Waste Cocking Oil used for testing.

\begin{tabular}{|l|l|l|l|l|}
\hline $\begin{array}{l}\text { Specific } \\
\text { Gravity }\end{array}$ & $\begin{array}{l}\text { Calorific } \\
\text { Value } \\
(\mathrm{KJ} / \mathrm{kg})\end{array}$ & $\begin{array}{l}\text { Kinetic } \\
\text { Viscosity } \\
{[\mathrm{cst}] \text { at }} \\
40^{\circ} \mathrm{C}\end{array}$ & $\begin{array}{l}\text { Flash } \\
\text { Point } \\
\left({ }^{\circ} \mathrm{C}\right)\end{array}$ & $\begin{array}{l}\text { Fire } \\
\text { Point } \\
\left({ }^{\circ} \mathrm{C}\right)\end{array}$ \\
\hline 0.904 & 35000 & 32.075 & 152 & 158 \\
\hline
\end{tabular}

\section{LITERATURE REVIEW}

\subsection{Introduction}

Vegetable oil is a renewable fuel. Recently, the vegetable oils are getting more appreciation due to the environmental benefits it provides \& being formed from an inexhaustible resource. Vegetable oil fuels were not feasible as they were costlier than petroleum based fuels. However, due to the increasing prices of petrol \& suspicions regarding the availability of it, interest is again getting increased for the vegetable oils. Vegetable oil can be a good replacement due to its advantageous properties.
Complete combustion of a fuel needs in existence a good quantity of stoichiometric oxygen. However, generally it isn't sufficient for complete combustion because it is not oxygenated. The amount of structural oxygen in fuel raises the efficiency of the fuel because of higher mixing of oxygen with the fuel during combustion. Thus, the combustion efficiency \& cetane no. of vegetable oil are more than that of diesel.

The demerits of vegetable oils which is used instead of diesel are:

- More viscous

- Lessvolatile

- Reactivity of unsaturated hydrocarbon chains

Problems arise when the engine is allowed to work on vegetable oils for a longer span of time, especially with dir. injection types. Major difficulties with vegetable oils are (a) chocking (b) depositing of carbon, (c) oil ring gets stuck, \&(d) lubricating oil gets thick\& starts gelling due to contamination. The researchers conducted by various researchers are discussed below.

\subsection{Waste Cocking oil (WCO) as alternative to} diesel

M. Canakci (2011) Waste cooking oil can be used in the place of virgin vegetable oil for production of biodiesel. In hotels \& other food companies, the waste cooking oil is either thrown or allowed to flow in the river or dumped into the land. Inspite of this, the waste cooking oil can be used for biodiesel production.

B. Supple, R. Howard-Hildige, E. Gonzalez-Gomez, and J. J. Leahy (2011) Biodiesel production from waste cooking oil is economically feasible. Authors did heating Treatment on waste cocking oil.

D. Y. C. Leung, X. Wu, and M. K. H. Leung (1998) the property of biodiesel is totally dependent on the type of fresh cooking oil used.

\subsection{Acid Catalysis for Biodiesel Production}

Jon Van Gerpen (2007), Biodiesel processing and production (2007) University of Idaho, Moscow USA. Biodesel Production Techniques are Acid catalysis, Base Catalysis, Enzymatic conversion, Solid catalysts, Non catalytic conversion, Super-critical Methanolysis. Enzymatic conversions are expensive and unable to provide to meet ASTM Fuel specification. For Solid catalysis High pressure and temperature arrangements are required. Non catalytic conversion Large set-up and Extreme operation conditions are required Only base and acid catalysis are simple and feasible techniques to local researchers out of which when Free Fatty Acid contents are more than 5\% then there will be more soap formation and wastage of base catalyst so it is unfavorable in such cases so remaining Acid catalysis is used when FFA content are more than 5\% in feedstock oil. These paper concluded benefit of using acid catalyst for low cost high free fatty acid contained feed stock. 
Ayhan Demirbas (2008) Transesterification methods comparison for production of biodiesel from vegetable oils and fats .These Paper concluded that the use of Phosphoric and sulphonic acid as catalyst for the biodiesel production is beneficial.

G.I. Keim (2012) Use of Acid for Neutralization but a residual acid value equivalent to about $5 \%$ palmitic acid. The unfinished reaction is may be because of the presence of water in the reactant mixture.

J.M.Marchetti, V.U. Miguel, A.F. Errazu (2012) possible methods for biodiesel production. Noureddini et al. have obtained good transesterification kinetics for acid catalyzed reaction for soybean oil.

M. Canakci, J. Van Gerpen (2013) Production of biodiesels by acid catalysis. Acid-catalyzed transesterification takes more time than alkali-catalyzed. The efficiency of converting ester is greatly affected due to molar proportion of alcohol to oil. In esterification, a high molar ratio is needed than acid-catalyzed that of alkalicatalyzed. The water in the oil strongly inhibits the ester conversion. If the water concentration is higher than 0.5 percent, the ester conversion rate can lower down to 90 percent.

\section{FreedmanB, ButterfieldR, PrydeE(2005)}

Transesterification kinetics of soybean oil. JAOCSFreedman and Pryde get the required product with 1 mol. percent of sulfuric acid with a ratio of moles of 30:1 at 65 deegreeC and they get $99 \%$ of conversion in $50 \mathrm{~h}$, while the butanolysis will need 117 deegreeC and the ethanolysis 78 deegreeC but the times should be 3 and $18 \mathrm{~h}$, respectively.

Gerhard Knothe(2013) Both constituents the fatty acid(oil) and alcohol i.e. methanol, can have great effect on properties of fuel such as cetane number with reference to exhaustand combustion emissions, oxidative stability, cold flow,lubricity\& viscosity.

\section{CONCLUSION}

Conventional process has an alkali catalyzed process, but this method found to be unsatisfactory for feedstocks which content freer fatty acid but this feedstock is lower in cost. The cost associated with using enzyme catalyst is high and it is unable to meet specification, heterogeneous catalysts requires high pressure and temperature conditions and Non catalytic as well as super critical methanolysis require large set-up and extreme operation conditions which required extreme engineering. In future, pretreatment processes that use strong catalysts may be proven to give better conversion yields and good-quality products. The acid catalysis is inviting method for producing bio-diesel. To evaluate the Productivity of biodiesel produced via Nitric Acid, Hydrochloric Acid and Sulfuric Acid is future scope for production of biodiesel

\section{REFERENCES}

[1] Sastry GSR, Krishna Murthy ASR, Ravi Prasad P, Bhuvaneswari K, Ravi PV.(2006) Identification and determination of bio-diesel in Diesel Energy Sources Part A;28:1337-42.

[2] Knothe G, Dunn RO, Bagby MO (1997). Biodiesel: the use of vegetable oils and their derivatives as alternative Diesel fuels. Am Chem Soc Symp Series; 666:172-208.

[3] Hama S, Yamani H, Kaieda M, Oda M, Kondo A, Fukuda H (2004). Effect of fatty acid membrane composition on whole-cell biocatalysts for biodieselfuel production. Biochem Eng J; 21:155-60.

[4] Oda M, Kaieda M, Hama S, Yamaji H, Kondo A, Izumoto E, et al.(2004) Facilitatory effect of immobilized lipase-producing Rhizopus oryzae cells on acyl migration in biodiesel-fuel production. Biochem Eng J; 23:45-51.

[5] Shieh C-J,Liao H-F, LeeC-C.(2003) Optimization of lipase-catalyzed biodiesel by response surface methodology.Biores Technol;88:103-6.

[6] Noureddini H, Gao X, Philkana RS. (2005) Immobilized pseudomonas cepacia lipase for biodiesel fuel production from soybean oil. Biores Technol; 96:769-77

[7] Demirbas A (2003). Biodiesel fuels from vegetable oils via catalytic and noncatalytic supercritical alcohol transesterifications and other methods: a survey. Energy Convers Manage; 44:2093-109.

[8] Noureddini H, Gao X, Philkana RS. (2005) Immobilized pseudomonas cepacia lipase for biodiesel fuel production from soybean oil. Biores Technol; 96:769-77.

[9] Barnwal BK, Sharma MP. (2005) Prospects of Biodiesel production from vegetable oils in India. Renew Sust Energy Rev;9(4):363-78.

[10] Srivastava A, Prasad R. (2000) Triglycerides-based diesel fuels. Renew Sust Energy Rev; 4:111-33.

[11] Ma F, Hanna MA. (1999) Biodiesel production: a review. Bio resource Technology; 70:1-15

[12] Fukuda H, Kondo A, Noda H (2001). Biodiesel fuel production by transesterification of oils. J Biosci Bioeng ; 92(5):405-16

[13] Barnwal BK, Sharma MP. (2005) Prospects of Biodiesel production from vegetable oils in India. Renew Sust Energy Rev; 9(4):363-78.

[14] Y, Dube' MA, McLean DD, Kates M. (2003) Biodiesel production from waste cooking oil: 1 . Process design and technological assessment. Bioresource Technol; 89:1-16.

[15]Freedman B, Pryde EH, Mounts TL (1984). Variables affecting the yields of fatty esters from transesterifiedvegetable oils. JAOCS;61(10):1638-43.

[16] Noureddini H, Zhu D (1997). Kinetics of transesterification of soybean oil. JAOCS;74(11):145763. 